\title{
Maintaining a Healthy Water Supply While Growing a Healthy Food Supply: Legal Tools for Cleaning Up Agricultural Water Pollution
}

\author{
Mary Jane Angelo ${ }^{1}$ \\ Jon Morris ${ }^{2}$ \\ INTRODUCTION
}

Agriculture provides the food, fuel and fiber that support human civilization. As the global population grows, more and more demands will be placed on our agricultural system to produce ever greater crop yields. Unless new strategies are employed, the pressure to increase production will exacerbate the environmental impacts of high intensity industrialized agriculture. Although agriculture is one of the most significant and pernicious causes of water pollution in the U.S., federal environmental laws designed to protect water resources exclude or exempt most agricultural activities. State efforts to address water quality impacts from agriculture have met with little success. The challenge of finding a way to reduce agricultural water pollution without causing severe economic harm to farmers is one of the greatest environmental challenges of our time.

Large scale industrialized agriculture, with its heavy reliance on fertilizer, pesticide and water inputs, is a major contributor to water pollution. Agricultural practices can cause serious adverse impacts to the quality of both groundwater and surface water. Rain or irrigation water that falls on farm fields picks up water soluble pesticides such as atrazine and nutrients such as nitrites found in fertilizers, causing them to leach into groundwater. Rain and irrigation water that is not absorbed into the soil runs off of agricultural fields carrying with it a variety of pollutants which ultimately end up in surface waterbodies. Run-off from farm

1. Professor of Law \& Director, Environmental and Land Use Law Program University of Florida Levin College of Law. I would like to thank UF Law Student and former potato farmer, Christopher Johns, for research assistance and for providing insight into farming practices in Florida.

2. University of Florida Levin College of Law, J.D. expected May 2014. 
fields frequently contains high levels of sediments from soil erosion from tilled fields, pesticides and fertilizers. Pesticides that enter waterbodies can adversely impact aquatic life. Nutrients from fertilizers can cause waterbodies to be hyper-eutrophied, which can severely impact submersed plants and aquatic animals. Run-off of sediments from soil erosion due to tilling can clog streams and fill in shallow areas in waterbodies, thereby reducing habitat and light availability to submersed plants. A report by the National Water Quality Inventory identified agricultural nonpoint source (NPS) pollution as "the leading source of water quality impacts on surveyed rivers and lakes, the second largest source of impairments to wetlands, and a major contributor to contamination of surveyed estuaries and ground water." 3

The federal Clean Water Act (CWA), ${ }^{4}$ the primary federal authority for addressing water pollution, has been largely successful at reducing water pollution from point sources (PS) such as wastewater treatment plants and industrial discharges through the National Pollutant Discharge Elimination System (NPDES). A major shortcoming of the NPDES program, however, is that it does not apply to NPS discharges, including most agricultural run-off. Because most pollutant discharges to waterbodies from agriculture are not subject to NPDES regulation, responsibility for addressing agricultural water pollution has fallen largely to the states. To date, the vast majority of state programs have been voluntary or incentive-based programs designed to encourage farmers to implement Best Management Practices (BMPs) to reduce runoff of contaminated water. These programs have had very limited success, and therefore, agricultural pollution continues to be one of the most significant sources of water quality degradation in the U.S. Accordingly, a further evaluation of the legal tools available to address the challenges of agricultural water pollution is warranted.

This article will explore a number of legal mechanisms that could play a role in ensuring that discharges from agricultural activities do not cause or contribute to violations of water quality standards. Specifically, this article will evaluate the relative effectiveness of: (1) narrative nutrient criteria as compared with numeric nutrient criteria; (2) TMDL implementation through regulatory and non-regulatory mechanisms; and (3) the relative efficacy of design-based standards such as BMPs and

3. Agricultural Nonpoint Source Fact Sheet, U.S. EnVIRONMENTAL Protection AgENCY (Mar. 2005), http://water.epa.gov/polwaste/nps/agriculture_facts.cfm.

4. Clean Water Act of 1972, 33 U.S.C. §§ 1251-1387 (2006). 
performance-based standards in reducing water pollution from agriculture. The article will draw on experiences from the State of Florida, including Everglades' restoration program and efforts, such as water quality trading programs, and efforts to reduce agricultural pollution in other states to demonstrate the efficacy of a variety of approaches. The article will suggest a multifaceted, watershed-based approach comprised of a combination of regulatory and non-regulatory tools designed to reduce nutrient pollution from agricultural run-off.

\section{Agricultural NUTRIENT POLLUTION}

Nutrient run-off from agricultural fertilizer is one of the leading causes of water pollution in the U.S. Throughout much of our agricultural history, nutrients needed to grow crops came from the nutrient-rich soils in which the crops were grown. ${ }^{5}$ However, in geographic regions lacking nutrient-rich soils, supplemental nutrients were provided either by the use of animal wastes (manure) or plant compost. Natural fertilizers such as animal manure have long been used to provide the nutrients necessary to grow crops. ${ }^{6}$ In addition, farmers frequently enriched soils by planting crops rich in nutrients as "green manure."7 Typical farming practices included crop rotation, covercropping, and intercropping with nitrogen-fixing legume crops which add nutrients to the soil.

The technical advances of the "Green Revolution" of the 1960's transformed the way farming is done in the U.S. The focus of the Green Revolution was on maximizing crop yields for a growing global population. ${ }^{8}$ To do so, it was necessary to supplement human labor with large inputs of synthetic fertilizers, as well as heavy inputs of pesticides and water. 9 During this time, agricultural systems evolved from being nutrient "sinks," wherein crop plants absorbed nutrients and incorporated them into plant tissue, into nutrient "sources," in which plant crops could

5. See James F. Parr \& Sharon B. Hornick, Agricultural Use of Organic Amendments: A Historical Perspective, 7 AM. J. Alternative AGRIC. 181-89 (1992) (providing an extensive history of fertilization methods).

6. Id.

7. See Michael Pollan, The Omnivore's Dilemma: A Natural History of Four MEALs 210-13 (2006) (explaining that green manure can provide the nutrients that crops need to grow effectively).

8. William S. Eubanks II, A Rotten System: Subsidizing Environmental Degradation and Poor Public Health with Our Nation's Tax Dollars, 28 STAN. ENVTL. L.J. 213, 251 (2009).

9. Id. at 255 . 
only absorb a small percentage of the large amount of fertilizer applied to the field. Nutrients that were not used by the plants became a source of pollution. ${ }^{10}$ For example, during the past 50 years, in excess of 600 tons of phosphorous were applied to agricultural lands globally, with only about 250 tons being removed by the plant. ${ }^{11}$

One of the most significant changes that occurred as part of the Green Revolution was the separation of animal livestock production from plant crop production. Animal wastes, previously relied upon to enrich cropland with nutrients were no longer on the same site as the cropland. Vast quantities of concentrated animal waste, generated on feedlots, became a significant water quality concern and the lack of animal waste on the croplands created the need to bring in synthetic fertilizers. $^{12}$ What had been a mutually beneficial system in which animal wastes fertilized the crops that fed the animals in a relatively "closed loop" system, with minimal pollution, became a serious environmental problem. ${ }^{13}$

The Green Revolution was a huge success in that it dramatically increased per acre crop yields. During this period, new federal government policies that linked subsidies to production levels further encouraged high-yield farming. ${ }^{14}$ Increases in government funding for research and development on high yield agriculture techniques coupled with education of farmers in these techniques by the network of agricultural extension agents also contributed to the dramatic rise in high-yield commodity farming. ${ }^{15}$ The Green Revolution is considered a major success in that it is estimated to have resulted in an increase of more than $150 \%$ in farm production over the past 60 years. ${ }^{16}$

10. See A. N. Sharpley et al., Agric. Research Serv., Best Management Practices To Minimize Agricultural Phosphorus ImPaCts ON WATER QUality 1-3 (U.S. Dept. of Agric. 2006), available at http://www.ars.usda.gov/is/np/BestMgmtPractices/Best\%20 Management\%20Practices.pdf (using phosphorus as an example of a nutrient that creates environmental problems through water eutrophication).

11. Id. (noting that in the U.S., approximately 4.5 metric tons of phosphorous have been used as fertilizer each year since 1994); see also U.S. Geological Survey, FerTILIZERS - SUSTAINING GLOBAL FOOD SUPPLIES, http://pubs.usgs.gov/fs/fs155-99/fs155-99.html (last visited Feb. 19, 2014).

12. See Eubanks, supra note 8, at 260.

13. See id. at 259-60 (comparing waste in pre-Green Revolution times to modern environmental problems).

14. Karen R. Hansen, Agricultural Nonpoint Source Pollution: The Need for an American Farm Policy Based on an Integrated Systems Approach Recoupled to Environmental Stewardship, 15 HAMLine J. PUB. L. \& POL’Y 303, 307-08 (1994).

15. See Mary Jane Angelo, Corn, Carbon, and Conservation: Rethinking U.S. Agricultural Policy in a Changing Global Environment, 17 GEO. MASON L. REV. 593, 602 (2010).

16. Agricultural Productivity in the United States, U.S. DEPARTMENT OF AGRICULTURE 
Unfortunately, the heavy inputs of fertilizers, pesticides and water necessary to obtain those high yields also caused significant environmental impacts, including degradation of the nation's waters. ${ }^{17}$

According to the EPA's 2000 National Water Quality Inventory, NPS pollution is the most significant source of water-quality impacts on surveyed rivers and lakes and the second leading source of contamination to groundwater and estuaries. ${ }^{18}$ A 2009 report identified nutrient water pollution as one of the most significant water quality and public health concerns in the country. ${ }^{19}$ According to the report, significant increases in nutrient pollution in U.S. waterbodies over the past 50 years have significantly impacted "drinking water supplies, aquatic life and recreational water quality." 20 The report identifies nutrient pollution as the cause of water quality impairment for approximately $20 \%$ of river and stream miles (approximately 80,000 miles), $22 \%$ of lake acres, and $8 \%$ of bay and estuary miles. ${ }^{21}$ According to the report "[n]utrient pollution from row crop agricultural operations, a by-product of excess manure and chemical fertilizer application, is the source of many local and downstream adverse nutrient-related impacts. $" 22$

Modern industrial agriculture relies on synthetic fertilizers derived from fossil fuels to provide the nutrients (nitrogen, phosphorous and potassium) needed to promote plant growth and provide high crop yields. ${ }^{23}$ The nutrients contained in these fertilizers, particularly nitrogen and phosphorous, can cause substantial environmental harms if they are transported into waterbodies. ${ }^{24}$ Just as these nutrients promote crop growth on the farm, they also promote algae growth in the water. Excess

ECONOMIC RESEARCH SERVICE (Sept. 27, 2013), http://www.ers.usda.gov/dataproducts/agricultural-productivity-in-the-us.aspx\#2010-2-1.

17. See Angelo, supra note 15, at 602; Eubanks, supra note 8, at 251-52, 260 (pointing to environmental effect of high-yield-crop technology).

18. Agricultural Nonpoint Source Fact Sheet, U.S. EnVIRonmental Protection Agency (2005), http://water.epa.gov/polwaste/nps/agriculture_facts.cfm.

19. State-EPA Nutrient InNOvations Task Group, An Urgent Call to ACtion: REPORT OF THE STATE-EPA NUTRIENT INNOVATIONS TASK GROUP 1 (2009), available at http://www2.epa.gov/sites/production/files/documents/nitgreport.pdf [hereinafter State-EPA Report].

20. Id. at 2 .

21. Id. at 5 .

22. Id. at 17 .

23. Nutrient Management and Fertilizer, U.S. Environmental Protection AgenCy (Nov. 14, 2012), http://www.epa.gov/oecaagct/tfer.html.

24. Jan Lewandrowski et al., The Interface Between Agricultural Assistance and the Environment: Chemical Fertilizer Consumption and Area Expansion, 73 LAND ECON. 404, 407 (1997). 
nutrients in waterbodies can result in rapid algal growth. ${ }^{25}$ An overabundance of algae depletes oxygen and blocks sunlight penetration, resulting in a condition referred to as eutrophication. ${ }^{26}$ Eutrophication can lead to significant and sometimes irreversible damage to lakes, rivers, and coastal oceans. Damage includes, among other things, blooms of algal species that may be toxic or harmful to humans and aquatic life, death of coral reefs and loss of coral reef communities, decreases in water transparency, problems with taste and odor of water, increased incidence of fish kills, shifts in pollution of fish species away from desirable species to "trash" species, and overall decreased aesthetic value of the waterbody. ${ }^{27}$

Although excessive nutrients can cause serious problems in virtually any waterbody, one of the most significant harms occurs when nutrientladen water flows into estuarine areas and causes hypoxic areas or "dead zones" in areas that previously had high fish and aquatic organism productivity. ${ }^{28}$ One notable dead zone is in the northern portion of the Gulf of Mexico, where both the Mississippi and Atchafalaya Rivers spill into the gulf. Agricultural activities in the Mississippi River basin are believed to account for approximately $66 \%$ of the nitrogen entering the gulf. ${ }^{29}$ Nitrogen and phosphorous from both agriculture and urban runoff are washed into the tributaries of the Mississippi River and ultimately flow downriver until they reach the Gulf of Mexico. ${ }^{30}$ These nutrients promote blooms of algae, bacteria, and cyanobacteria, ${ }^{31}$ which ultimately result in depletion of oxygen, or hypoxia. ${ }^{32}$ The hypoxic area, or dead

25. Eubanks, supra note 8 , at 256.

26. See id. (" $[\mathrm{A}] \mathrm{s}$ more algae is created from increased chemical nutrients in the water, less oxygen is available for phytoplankton and other organisms in the aquatic ecosystem. When the oxygen slips below a certain level, the water takes on the effects of hypoxia, or a shortage of oxygen. A hypoxic area quickly becomes a 'dead zone' because fish and other mobile organisms leave due to the lack of oxygen and all other organisms will die off and cause a food chain collapse."); SHARPLEY ET AL., supra note 10, at 1 (explaining effect process of phosphorous biosphere contamination).

27. S.R. Carpenter et al., Nonpoint Pollution of Surface Waters with Phosphorus and Nitrogen, 8 ECOLOGICAL APPLICATION 559, 561 (1998).

28. Eubanks, supra note 8, at 256.

29. Id.

30. John A. Downing et al., Gulf of Mexico Hypoxia: Land-SeA Interactions 1-2 (Council for Agric. Sci, \& Tech. 1999).

31. U.S. ENVIRONMENTAL PROTECTION AgENCy SCI. AdVISORy BD., EPA-SAB-08-003, Hypoxia in the Northern Gulf of MeXico: An Update by the EPA SCIENCE AdVisory BOARD 10 (2007), available at http://yosemite.epa.gov/sab/sabproduct.nsf/C3D2F27094E03F90852573B800601D93/\$File/EPASAB-08-003complete.unsigned.pdf.

32. Id.; DOWNING ET AL., supra note 30, at 5. 
zone, in the northern Gulf of Mexico covers 16,500 square kilometers $(10,250$ square miles) along the coast. The Gulf of Mexico dead zone is the largest of the hypoxic zones in the U.S.; however, numerous other large waterbodies in the U.S. are impacted by excess nutrients from agricultural run-off. Examples include the Chesapeake Bay ${ }^{33}$ and the Florida Everglades, among many others. ${ }^{34}$

\section{The Federal CleAn WATER ACT}

In 1972 Congress enacted amendments to the Clean Water Act (CWA), which significantly improved the federal government's ability to regulate pollution entering into U.S. waterbodies. ${ }^{35}$ Unfortunately, due to limitations of the CWA, many of the nation's waterbodies are still negatively impacted by water pollutants. Specifically, the inability of the CWA to meaningfully reduce the discharge of pollutants from NPS pollution, predominantly agriculture, has led to increased nutrient loading into waterbodies. ${ }^{36}$ NPS pollution is difficult to regulate because there are generally no end of pipe discharges that can be measured and monitored. ${ }^{37}$ NPS polluters are not regulated by the National Pollutant Discharge Elimination System (NPDES), the main regulatory tool that is used to control pollutant discharge into waterbodies. ${ }^{38}$ The current NPDES program regulates PS pollution but fails to account for the significant pollutant discharge coming from NPS.

\section{A. The National Pollutant Discharge Elimination System Permitting Program}

The most significant regulatory program in the CWA is the NPDES

33. Rita Cestti et al., Agriculture non-Point Source Pollution Control: Good MANAgEMent Practices-The ChesapeAKe BAy EXPERIENCE 1 (World Bank 2003).

34. Steven M. Davis, Phosphorus Inputs and Vegetation Sensitivity in the Everglades, in Everglades: The ECOSYSTEM AND Its Restoration 357, 359 (Steven M. Davis \& John C. Ogden eds., St. Lucie Press 1994).

35. U.S. EnVIronmental Protection Agency OfFice of Water, Water Quality TRADING POLICY STATEMENT (2003), available at http://water.epa.gov/type/watersheds/trading/upload/2008_09_12_watershed_trading_finalpolicy200 3.pdf.

36. See Corey Longhurst, Where is the Point? Water Quality Trading's Inability to Deal with Nonpoint Source Agricultural Pollution, 17 DRAKE J. AGRIC. L. 175, 182 (2012) (noting use of nitrogen and phosphorus fertilizer has grown dramatically since the 1960s).

37. See id. at 182 (stating it is difficult to trace pollution back to specific farms).

38. Id. at 178. 
permitting program found in section 402 of the Act. ${ }^{39}$ Section 301 of the CWA prohibits "the discharge of any pollutant" to navigable waters from point sources unless the discharge is in accordance with an NPDES permit under section $402 .^{40}$ This section creates what is in essence a four-part test for determining whether a NPDES permit is required. A NPDES permit is required for (1) any discharge (2) of a pollutant (3) from a point source (4) into navigable waters.

The CWA does not contain a definition of "nonpoint source." The EPA considers a "nonpoint source" to be "any source of water pollution that does not meet the legal definition of 'point source' in section 502(14) of the Clean Water Act." 41 Accordingly, any source that is not a point source is a "nonpoint source." The definition of "point source" found in section 502(14) of the CWA clearly excludes agricultural runoff:

[A]ny discernible, confined and discrete conveyance, including but not limited to any pipe, ditch, channel, tunnel, conduit, well, discrete fissure, container, rolling stock, concentrated animal feeding operation, or vessel or other floating craft, from which pollutants are or may be discharged. This term does not include agricultural stormwater discharges and return flows from irrigated agriculture. ${ }^{42}$

Agricultural discharges that are excluded from the definition of PS are not regulated under the NPDES program. In fact, the CWA does not provide for any direct regulation of agricultural NPS pollution but instead contemplates state planning and regulation to address NPS pollution. Section 208 of the CWA calls for states to adopt "areawide waste treatment management plans," which can include state controls on NPS water pollution. ${ }^{43}$ Congress's intent to exclude agricultural NPS from the NPDES program is further evidenced by the 1987 CWA amendments, which brought certain stormwater discharges within the purview of the NPDES program, but continued to exclude agricultural stormwater discharges from the permitting program. ${ }^{44}$

\footnotetext{
39. 33 U.S.C. $\$ 1342$ (2012).

40. 33 U.S.C. § 1311(a) (2012).

41. What is Nonpoint Source Pollution?, U.S. EnVIRonmental PROtection Agency (July 29, 2012), http://water.epa.gov/polwaste/nps/whatis.cfm.

42. 33 U.S.C. $\$ 1362(14)$ (2012) (emphasis added).

43. 33 U.S.C. $\$ 1288$ (2012).

44. 33 U.S.C. $\$ 1342(\mathrm{p})(2)(2012)$.
} 


\section{B. Effluent Limitations and Water Quality Standards}

An understanding of how the NPDES program has resulted in significant reduction of PS pollution is necessary to see how efforts to reduce NPS pollution have fallen short. PS discharges that meet the four-part test are required to be authorized by NPDES permits issued by a permitting authority - either the EPA or a state to which the EPA has delegated the authority to implement the program. ${ }^{45}$ The permitting authority must ensure that the NPDES permits it issues contain limitations that both comply with specified technology-based standards and assure compliance with state water-quality standards. Technologybased standards are established on an industry-wide basis to ensure that polluters are reducing pollutants in their discharges to the extent feasible. ${ }^{46}$ The CWA provides for different types of technology-based standards that apply with varying levels of stringency and differences in the extent to which economic considerations are taken into account. A number of factors, including the type of pollutants being discharged and whether the source is considered a new source or whether it existed prior to the implementation of the CWA, determine which technology-based standards apply to a particular source. ${ }^{47}$ The federal EPA will survey the particular industry to determine what pollution reduction technology is available and feasible to establish a numeric performance standard for that industry. The EPA adopts by rule the numeric performance standard as a technology-based "effluent limitation guideline," which is included in NPDES permits issued for sources in that particular industry. ${ }^{48}$ For most of the history of the NPDES program these technology-based performance standards included in NPDES permits as "effluent limitations" have driven pollution reductions. Only recently, when it has

\footnotetext{
45. 33 U.S.C. $\$ 1311$ (2012).

46. J.B. Ruhl, Agriculture and Ecosystem Services: Paying Farmers to Do the New Right Thing, in FoOD, Agriculture, \& ENVironmental Law 249 (Angelo, Czarnezki, \& Eubanks, eds., 2013). See also 33 U.S.C. $\S § 1311-17,1342$ (2012).

47. Three different technology-based standards exist under the CWA. The applicable technology is determined based on the type of pollutant discharged and whether the discharging source is new or existing. JACKSON B. BATTLE \& MAXINE I. LIPELES, WATER POLLUTION 167 (3d ed. 1998). "Best available technology" is the technology-based standard applied to existing sources of nonconventional and toxic pollutants. 33 U.S.C. $\$ 1311$ (b)(2)(A) (2008). "Best conventional technology" is applied to existing sources of conventional pollutants. Id. "Best available demonstrated control technology" is the technology-based standard applied to new sources of water pollutants. 33 U.S.C. § 1316(a)(1); see also BP Exploration \& Oil, Inc. v. U.S. E.P.A., 66 F.3d 784, 789-90 (6th Cir. 1995) (explaining the different standards EPA uses to control pollutants under the CWA). For an extensive overview of water law, see generally BATTLE \& LIPELES, supra note 47.

48. 33 U.S.C. $§ 1342$ (2012). See also 40 C.F.R. $§ 122.21$ (2012).
} 
become apparent that imposing technology-based standards on PS polluters is not sufficient to clean up many of the nation's waters, have water quality standards (WQS) begun to play a much more significant role for both PS and NPS pollution.

The CWA requires each state to establish WQS for each water body within its jurisdiction. WQS are comprised of (1) a determination of designated use; (2) water quality criteria; and (3) antidegradation standards. $^{49}$ In setting WQS, each state must first establish the "designated use" of each water body within the state. ${ }^{50}$ For example, in the State of Florida, the state may designate a particular waterbody for drinking water, for shellfish harvesting, for fishing and swimming, for agricultural use, or for industrial use. Once the state has established the designated use of a particular waterbody, it must develop water quality criteria for particular pollutants necessary to protect that designated use. Water quality criteria are typically presented as numeric criteria; however, for nutrients, most states' water quality criteria are expressed in a narrative form. ${ }^{51}$

The intent of the CWA is that NPDES permits contain effluent limitations that comply with both technology-based standards and water quality standards. Where technology-based standards are not adequate to protect a designated use, NPDES permits must contain water quality based effluent limitations. ${ }^{52}$ Because NPS discharges are not subject to NPDES permitting requirements, there is no federal tool for imposing effluent limitations on NPS polluters. Nevertheless, as described below, WQS are intended to protect designated uses from both NPS as well as PS pollution.

\section{Total Maximum Daily Loads}

The CWA requires each state to identify the waterbodies within the state for which "the effluent limitations ... are not stringent enough to implement any water quality standard applicable to such waters" and to rank such waterbodies based on priority, "taking into account the severity of the pollution and the uses to be made of such waters." CWA further directs each state to establish for "the waters identified in

\footnotetext{
49. BATTLE \& LIPELES, supra note 47, at 182.

50. See id. at $182-83$.

51. See id. at 183-84.

52. See id. at 181-82.

53. 33 U.S.C. $§ 1313(d)(1)(A)(2012)$.
} 
paragraph (1) (A) of this subsection, and in accordance with the priority ranking," the total maximum daily load (TMDL). The TMDL is to be set at "a level necessary to implement the applicable water quality standards with seasonal variations and a margin of safety that takes into account any lack of knowledge concerning the relationship between effluent limitations and water quality." ${ }^{54}$ States are required to submit to the EPA the "waters identified and loads established" for review and approval by the EPA. If disapproved, or if a state fails to develop the needed TMDLs on a timely basis, the EPA will develop the TMDLs for the state.

TMDLs are the means by which water quality criteria can be translated into water-quality based effluent limitations in NPDES permits, or other types of pollution limitations under state regulatory programs. As such, TMDLs play a critical role in protection of water quality, particularly from NPS pollution. ${ }^{55}$ The CWA defines a TMDL as the sum of allocated loads of pollutants, set at a level necessary to implement the applicable WQS, including waste-load allocations from PS, load allocations from NPS, and natural background conditions. ${ }^{56}$ Thus, TMDLs are to include both PS and NPS discharges. ${ }^{57}$ The CWA also requires that a TMDL contain a "margin of safety" and take into consideration "seasonal variations." 58

A TMDL represents, in essence, the amount of a particular pollutant that a particular water body can assimilate without resulting in a violation of a WQS. Despite the CWA's mandate that states develop TMDLs starting in the 1970s, most states did not begin to establish TMDLs until pressured to do so by litigation. Starting in the mid-1990s, environmental organizations initiated a spate of lawsuits against the federal EPA seeking to compel the EPA to adopt TMDLs in instances where states had failed to do so. This litigation prompted many states to step up and begin to establish their own TMDLs in an effort to avoid the federal EPA setting the TMDLs for them. ${ }^{59}$ Although many states began working on TMDLs in the mid-1990s, to date most states still have not established TMDLs for many of the waterbodies within their

\footnotetext{
54. 33 U.S.C. $§ 1313(d)(1)(C)(2012)$.

55. For historical perspective on TMDLs, see OLIVER HOUCK, THE CLEAN WATER ACT TMDL PROgRAm: LAW, Policy, AND IMPLEMENTATION (Envtl. Law Inst. ed., 2d ed. 2002).

56. 33 U.S.C. $\$ 1313(\mathrm{~d})(1)(\mathrm{C})$; see also Ruhl, supra note 46 at 300-05 (discussing TMDLs).

57. See Pronsolino v. Nastri, 291 F.3d 1123, 1139 (9th Cir. 2002) (upholding EPA's interpretation that section 303(d) applies even to waterbodies impaired only by NPS).

58. 33 U.S.C. $§ 1313(d)(1)(C)(2012)$.

59. BATTLE \& LIPELES, supra note 47 , at 185.
} 
jurisdictions.

The process of establishing TMDLs can be extremely complex from a scientific standpoint. Detailed water quality data is a necessary starting point to understanding whether and to what extent a waterbody is impaired. Complex modeling that takes into account factors such as plant uptake of nutrients, the ability of soil to bind nutrients, resuspension of nutrients from bottom sediments, dilution, currents and flows, as well as many other factors, is typically used to predict the assimilative capacity of the waterbody. For example, assume a state designates a particular waterbody as a class III swimmable/fishable waterbody and that the numeric water quality criteria for the nutrient phosphorous is set as 55 parts per billion (ppb) - in other words, the phosphorus concentration in that waterbody must be at or below $55 \mathrm{ppb}$ for that waterbody to meet its designation as a class III fishable/swimmable water. Computer modeling will then be used to determine how much of a load of phosphorous - i.e., how many pounds of phosphorous can be discharged into that waterbody from all combined sources each day without the phosphorous concentration of the waterbody exceeding the $55 \mathrm{ppb}$ criterion. In reality, loadings are typically not established on a daily basis, but instead are set on an annual basis. In this example, assume that based on the data and computer modeling, the maximum annual loading of phosphorus that can be discharged into the waterbody without violating the water quality criteria designed to protect the designated use is fifteen tons per year (tpy). The fifteen tpy, which represents the total maximum annual load for phosphorus in that waterbody, must then be allocated among all sources of phosphorous. States must go through this process of setting TMDLs for every pollutant of concern in every water quality impaired waterbody or waterbody segment in the state. In many states, this can mean hundreds or even thousands of TMDLs must be established. This is an enormous undertaking and thus it is not surprising that it is taking considerable time for states to complete TMDL development, especially during times of tight state government budgets.

Even after the daunting task of setting TMDLs is complete, the job is not done. The next task is for the state to allocate each TMDL among all PS and NPS dischargers. A full understanding of all of the existing sources (including PS, NPS, atmospheric deposition, natural background and release from sediments) of pollutant loading to a waterbody is necessary to allocate a TMDL. TMDLs are allocated among PS discharges by including an effluent limitation in the NPDES permit for that source. TMDLs may require pollution reductions beyond what 
would be required using only technology-based effluent limitations in a

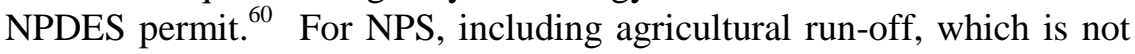
subject to NPDES permitting, the allocation and implementation of TMDLs is much more challenging. Most NPS discharges are not monitored or quantified. For the most part, states do not have detailed data on the amount of pollutant loadings coming off of any particular farm. Thus, the decision of what portion of a TMDL to allocate to a particular farm is challenging. As a result, most states have chosen not to make numerical allocations of TMDLs to farms.

Although establishing and allocating TMDLs is no easy matter, perhaps the greatest challenge is implementing the TMDL. To date, states have made little progress in reducing NPS discharges to meet TMDLs even where TMDLs are in place. In 2000, the EPA proposed a rule that would have required an implementation plan and funding source as part of any state TMDL that the EPA approved. ${ }^{61}$ The final rule was adopted with an effective date of 2003. However, in 2003, the EPA promulgated a rule withdrawing the 2000 revisions. ${ }^{62}$ This rule was never finalized, and thus, TMDL implementation remains the responsibility of the states. It is likely that a multifaceted, watershedbased approach that includes components such as: state regulation of urban, suburban, and agricultural run-off; adoption of BMPs to reduce pollutant loadings in stormwater and agricultural discharges; retrofitting existing urban areas to treat stormwater; land acquisition programs to protect riparian areas that provide the function of filtering pollutants from run-off; wetland and water body restoration programs; and public education will be needed to successfully implement TMDLs in most locales. ${ }^{63}$ In geographic areas with significant agriculture, a variety of regulatory and nonregulatory mechanisms including voluntary, incentive-based, or mandatory BMPs, state permitting programs to limit

\footnotetext{
60. Id. at 184 .

61. Revisions to the Water Quality Planning and Management Regulation and Revisions to the National Pollutant Discharge Elimination System Program in Support of Revisions to the Water Quality Planning and Management Regulation, 65 Fed. Reg. 43,586 (July 13, 2000) (to be codified at 40 C.F.R. pt. 9, 122, 123, 124, \& 130).

62. For a discussion of the politics behind the 2000 rule and the 2003 withdrawal of the rule, see Oliver A. Houck, The Clean Water Act Returns (Again): Part I, TMDLS and the Chesapeake Bay, 41 ENVTL. L. REP. NEws \& ANALYSIS 10208, 10210 (2011) (describing how one of the first acts of the Bush administration was to place the TMDL regulation on hold, thereby taking implementation plans off the agenda).

63. See generally Oliver A. Houck, TMDLs III: A New Framework for the Clean Water Act's Ambient Standards Program, 28 ENVTL. L. ReP. NEWS \& ANALYSIS 10415, 10423 (1998) (describing the new programs emerging from the EPA, states, and the federal government).
} 
agricultural discharges, farmer education and technical support, and preservation of riparian vegetated buffers along waterbodies running through or near agricultural lands must be considered.

\section{Narrative and Numeric Nutrient Criteria}

In many parts of the U.S., the two greatest water quality problems from NPS run-off are excessive algal production which decreases water clarity and decreases the abundance of rooted, submersed macrophyte beds; and excessive sedimentation which degrades benthic habitats and, through sediment resuspension, water quality. The causes of these problems are largely nutrients, such as nitrogen and phosphorus, and suspended matter.

A significant impediment to addressing nutrient problems is that, unlike most other pollutants of concern, most states do not have numeric water quality criteria for nutrients in place. Instead, most states rely on "narrative criteria" that describe the effect of nutrients on waterbodies. These narrative criteria do not provide a bright line for measuring compliance. For example, until recently, the state of Florida relied solely on the following narrative criteria that provide: "[i]n no case shall nutrient concentrations of a body of water be altered so as to cause an imbalance in natural populations of aquatic flora and fauna."

In other words, the Florida water quality criteria did not specify a concentration at which phosphorus or nitrogen levels in a particular waterbody would be considered a violation of state WQS. To determine compliance, it was necessary to conduct a qualitative analysis to determine whether nutrient concentrations were at unspecified levels that would cause an "imbalance" in population of aquatic flora, primarily algae, and fauna. Not only would numeric criteria provide a bright line needed to measure compliance, it also could be an important step in setting TMDLs for nutrients. The extent to which the nutrient concentrations in a waterbody deviate from the numeric nutrient criteria for that waterbody is the first step in determining how much nutrient loads must be reduced.

According to the most recent data provided by the EPA, only twentyfour states have adopted some form of numeric nutrient criteria. ${ }^{65}$ Of

64. Fla. AdMIn. CODE ANN. r. 62-302.530(47)(b) (2013).

65. State Development of Numeric Criteria for Nitrogen and Phosphorous Pollution, U.S. ENVIRONMENTAL PROTECTION AGENCY, http://cfpub.epa.gov/wqsits/nnc-development/ (last visited Feb. 27, 2014). 
these twenty-four states, only one, Hawaii, is currently classified as achieving level 5 status, ${ }^{66}$ which is designated for states that have a "complete set of $\mathrm{N}$ [itrogen] and $\mathrm{P}$ [hosphorous] criteria for all watertypes." ${ }^{\text {"67 }}$ Only three states, Wisconsin, New Jersey, and Florida, are classified as level 4 states, which is a designation for states that have " 2 or more watertypes with $\mathrm{N}$ [itrogen] and/or P[hosphorous] criteria." 68 Three states, Minnesota, West Virginia, and Rhode Island, are classified as level 3 states, which is a designation for states with " 1 or more watertype with N[itrogen] and/or P[hosphorous] criteria."69 Sixteen states are classified as level 2, a designation for states with "some waters with N[itrogen] and/or P[hosphorous] criteria."70 As of 2013, a slight majority of states, twenty-six out of fifty, have failed to enact any numeric nutrient criteria for any waterbodies within their territory; they are designated as level $1 .^{71}$

Projections provided by the states indicate that over the next three years marginal progress will be made with respect to implementing numeric nutrient criteria. ${ }^{72}$ By the end of 2014, Delaware, Minnesota, and New York, are slated to become level 4 states, while Vermont is projected to become the second level 5 state. ${ }^{73}$ By 2015, Mississippi, Indiana, Ohio, New York, New Hampshire, and Pennsylvania intend to introduce numeric criteria for the first time, with Ohio intending to become a level 5 state. $^{74}$ Based on current numeric criteria implementation and projections, by the end of 2016 nineteen states will still have no numeric criteria for nitrogen and phosphorous pollution in the waters of their territory. ${ }^{75}$

\section{STATE APPROACHES}

States have employed a number of different approaches to address

\footnotetext{
66. Id.

67. Id

68. Id.

69. Id.

70. Id. Alphabetically as follows: Arizona, California, Colorado, Delaware, Georgia, Illinois, Massachusetts, Missouri, Montana, Nebraska, Nevada, New Mexico, Oklahoma, Oregon, South Carolina, Vermont, Virginia.

71. Id.

72. Id.

73. Id.

74. Id

75. Id.
} 
pollution from agricultural run-off. The state approaches generally fall into three broad categories: (1) voluntary programs, which frequently include incentives such as financial or technical assistance from the state; (2) market-based approaches, which include water quality trading programs; and (3) direct regulation, which can include the direct imposition of requirements such as the use of BMPs or other regulatory requirements. To date, most states have relied heavily upon BMPs, either through direct imposition or voluntary programs that incentivize the use of BMPs. In recent years, some states have experimented with using water quality trading programs as a way to further reduce water quality degradation from agricultural run-off. These approaches, as implemented, have met with very limited success.

\section{A. Voluntary Approaches}

\section{Best Management Practices}

To date, most states have primarily relied on the use of BMPs to address water quality degradation from agricultural run-off. Agricultural BMPs "include soil and water conservation practices, other management techniques, and social actions" designed to reduce water pollution runoff from agriculture. ${ }^{76}$ BMPs vary from crop to crop and by geographic locale. Many agricultural BMPs involve irrigation and water management practices that are designed to reduce run-off. ${ }^{77}$ Common BMPs designed to address nutrient run-off include reduced fertilizer rates, time released fertilizer, and carefully timing fertilizer application to avoid heavy rainfall. ${ }^{78}$ Other BMPs seek to minimize the transport of nutrients by using cover crops, conservation tillage and contour farming to limit erosion, and by planting buffer strips and managing riparian zones to trap nutrients and disperse run-off. ${ }^{79}$ The costs of implementing BMPs can be high, particularly for practices that require installation of structures, or very low, as with altered timing of fertilizer application. ${ }^{80}$ The efficacy of BMPs varies greatly with the type of BMP and geographic region. ${ }^{81}$

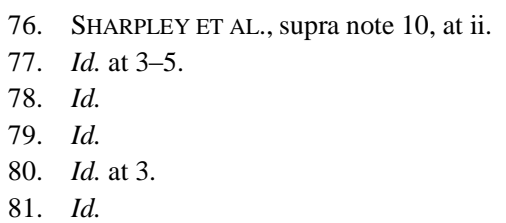


Perhaps the greatest concern with BMPs is that even if they are implemented by farmers, they may not reduce nutrient levels sufficiently to achieve compliance with WQS. The efficacy of a particular BMP will depend on a wide range of factors including BMP type, crop type, soil, soil type, land slope, proximity to waterbodies, and amount and timing of rainfall. Although a fair amount of research has been done on a number of BMPs, there is a dearth of comprehensive data to demonstrate the efficacy of different BMPs under varying conditions. Studies on BMP efficacy show reductions of phosphorous ranging anywhere from $0 \%$ to roughly $70 \% .^{82}$

Both the federal government and many states offer financial incentives to farmers who voluntarily participate in BMP programs or undertake pollution reduction measures. The primary federal program, the Environmental Quality Incentives Program (EQIP), is a voluntary program, administered by the Natural Resources Conservation Service (NRCS), which provides financial support and technical assistance to agricultural producers. ${ }^{83}$ Through EQIP, the NRCS manages operational plans designed to improve conservation and environmentally beneficial agricultural practices. ${ }^{84}$ The National Water Quality Initiative (NWQI) is a subprogram within EQIP that is designed to target specific important watersheds throughout the U.S. ${ }^{85}$ EQIP is implemented through the recurring farm bills, which generally modify the limits and structure of the program. ${ }^{86}$ The 1996 farm bill (The Federal Agriculture Improvement and Reform Act of 1996) set a limit of $\$ 10,000$ per fiscal year or $\$ 50,000$ per multi-year contract for a conservation project under EQIP. ${ }^{87}$ The 2002 farm bill (The Farm Security and Rural Investment Act of 2002) increased the statutory limits of the EQIP program, allowing for financial support of as much as $\$ 450,000$ during the 20022007 fiscal years. ${ }^{88}$ Critics of the increased limits suggest that higher

\footnotetext{
82. Id. at 28 .

83. Environmental Quality Incentives Program, U.S. DEPARTMENT OF AGRICUlture, NATURAL ReSOuRCES CONSERVATION SERviCE, http://www.nrcs.usda.gov/wps/portal/nrcs/main /national/programs/financial/eqip (last visited Feb. 28, 2014).

84. Id.

85. National Water Quality Initiative, U.S. DEPARTMENT OF AGRICULTURE, NATURAL RESOURCES CONSERVATION SERVICE, http://www.nrcs.usda.gov/wps/portal/nrcs/detail/national/ programs/financial/eqip/?cid=stelprdb1047761 (last visited Feb. 20, 2014).

86. Shauna R. Collins, Striking the Proper Balance Between the Carrot and the Stick Approaches to Animal Feeding Operation Regulation, 2012 U. ILL. L. REV. 923, 954-55 (2012).

87. Federal Agriculture Improvement and Reform Act of 1996, Pub. L. No. 104-127, § 334 (1996) (amended by 2002 Farm Bill).

88. Farm Security and Rural Investment Act of 2002, Pub. L. No. 107-171, § 1240G (2002)
} 
limits favor Concentrated Animal Feeding Operations (CAFOs). ${ }^{89}$ The 2008 farm bill (Food, Conservation, and Energy Act of 2008) reduced the maximum level of financial support to $\$ 300,000$, in theory decreasing the maximum a large CAFO might recoup through EQIP. ${ }^{90}$ However, the Secretary of the U.S. Department of Agriculture may waive the cap in situations of special environmental significance, in which case the cap may be raised to a maximum $\$ 450,000 .^{91}$

It is difficult to assess whether the increases in EQIP limits is a net positive or negative for the environment. It seems rational to conclude that the increase in overall funding for EQIP (approximately $\$ 200$ million in 1996 to approximately $\$ 1.75$ billion in 2008) has had a positive impact on environmental quality, at least in targeted areas. ${ }^{92}$ However, CAFOs are regulated under the CWA and might be forced into conservation practices without the financial assistance provided through EQIP. If the USDA concentrated EQIP funding on small-scale farming operations, CAFOs would still be required to meet applicable Technology Based Effluent Limitations or Water Quality Based Effluent Limitations. Assuming the funding for EQIP remained at the current statutory levels, the federal financial assistance would be freed to assist non-CAFO agricultural operations.

\section{Payments for Ecosystem Services}

Another tool that a government might employ in an effort to improve water quality is Payment for Ecosystem Services (PES). PES can represent a broad range of incentive-based government programs; however, a traditional PES program involves providing financial support for landowners (particularly agricultural) in exchange for some prescribed environmentally positive action. While modern, large-scale commercial agriculture is associated with negative environmental impacts, agriculture in a responsibly managed system can provide significant positive ecosystem services. ${ }^{93}$ A responsibly managed

(amended by 2008 Farm Bill).

89. See, e.g., Martha Noble, Paying the Polluters: Factories Feast on Taxpayer SUBSIDIES 223 (2010), available at http://www.cafothebook.org/download/CAFO_Paying_ the_Polluters.pdf.

90. Food, Conservation, and Energy Act of 2008, Pub. L. No. 110-246, § 2508 (2008) (amended by the 2014 Farm Bill).

91. Id.

92. Collins, supra note 86 , at 954.

93. Ruhl, supra note 46, at 245-46. 
agricultural system, funded in part with PES money, may provide buffer areas between pollutant generators and riparian waters, cleaner aquifer recharge areas, and native habitats for indigenous flora and fauna. ${ }^{94}$

One benefit of the PES tool is that it is preventative in nature, as compared to many contemporary reactive measures. Instead of having to expend tremendous sums of collected tax money building treatment facilities, it is likely more economically efficient to pay the farmers to implement ecologically beneficial services. ${ }^{95}$ For example, in central Florida, a PES program is directed at a large cattle industry, which is largely responsible for increased nutrient loading into Lake Okeechobee and eventually the sensitive Everglades. ${ }^{96}$ Funding under the PES program is used to pay ranchers for services that reduce phosphorous loading. ${ }^{97}$ This and other PES programs can be mutually beneficial, as farmers can secure a consistent stream of payments while the regulating government can reduce expenditures associated with the clean-up of polluted waters. ${ }^{98}$

The main drawback for PES programs is the need for consistent funding from either the federal or state government. One potential solution is to use money that traditionally went to farmers based on production and instead direct it towards providing financial assistance for providing ecologically beneficial services. As one author notes, we have already made a policy choice to pay farmers - the only philosophy change needed is to shift from a policy based on paying for quantity production to a more holistic approach of paying for ecosystem services. ${ }^{99}$

\section{B. Market-Based Approaches}

In recent years, several states have been experimenting with marketbased approaches to reduce NPS pollution. Several states have either implemented or are in the process of developing Water Quality Credit Trading (Trading) programs. Trading programs are designed to decrease pollution from both PS and NPS polluters. ${ }^{100}$ In theory, Trading

\footnotetext{
94. Id.

95. Id. at 253.

96. Id.

97. Id.

98. Id.

99. Id. at 241.

100. See, e.g., Longhurst, supra note 36, at 183-84 ("Under California law, all dischargers are
} 
programs allocate costs associated with the abatement or mitigation of water pollution in an economically efficient manner. ${ }^{101}$ Trading programs are promising because they are market-based theories that potentially allow for greater flexibility, reduced costs for polluters, and increased environmental benefits. ${ }^{102}$

The underlying premise is that PS polluters have been regulated to a point where any additional abatement will require sophisticated, costly techniques. Alternatively, since NPS pollution is not significantly regulated, there are cheaper abatement techniques that can be implemented. Under a Trading program, a NPS polluter (or PS polluter) implements an abatement technique that decreases the amount of discharge from his or her source. This action generates a credit that may be sold in an open market to a PS polluter that is struggling to find economical ways to abate pollution. These actions allow for society to realize the most economically efficient abatement of pollutants.

In 2003, the EPA issued a policy statement that explains specific parameters a state Trading program must follow in order to receive EPA support. ${ }^{103}$ The purpose of the policy statement was "to encourage states, interstate agencies and tribes to develop and implement water quality [T]rading programs for nutrients, sediments and other pollutants where opportunities exist to achieve water quality improvements at reduced costs."104 Specifically, the EPA sought to create voluntary incentive programs by which PS and NPS polluters are incentivized to reduce pollution in order to generate credits that they may sell in an open market. $^{105}$

1. Florida's Water Quality Trading Program

In 2008, the Florida Legislature authorized a pilot Trading program in the lower St. Johns River Basin. ${ }^{106}$ The Florida Department of

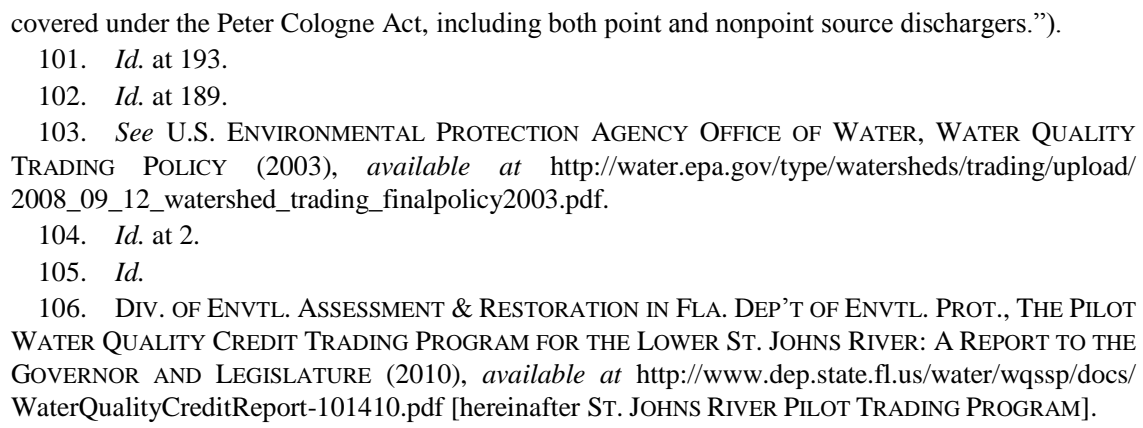


Environmental Protection (DEP) promulgated regulations to implement the pilot project. Credits generated by PS polluters must be verified through effluent monitoring. ${ }^{107}$ Credits generated by NPS polluters can be either measured through effluent monitoring or through estimation, so long as the estimation is coupled with reasonable assurances and an uncertainty factor is applied to the estimation. ${ }^{108}$ The quantity of credits generated by a PS polluter is the amount the source's load is reduced below the baseline established for the source. ${ }^{109}$ For a NPS polluter to generate a credit, it must reduce its load by more than what is expected following the implementation of applicable BMPs, which are required under the Basin Management Action Plan (BMAP) for that source. ${ }^{110}$ The requirements are designed to ensure that the Trading program is one in which a polluter must go above and beyond the baseline level of pollution reduction (BMP or load allocation) before it is capable of generating credits. A farmer wishing to generate a credit under the current rule would have to implement all required BMPs and further implement an additional action designed to reduce the amount of pollutant discharge.

The DEP rule sets forth five eligible ways to generate credits. A credit may be generated by: (a) installing or modifying water pollution control equipment, (b) implementing operational changes or modifying a process that results in a reduction of nutrient load discharge, (c) implementing NPS management controls, (d) installing and operating drainage projects designed to control stormwater, and (e) similar control methods that demonstrate an ability to reduce nutrient loading. ${ }^{11}$ Additionally, three activities that are not eligible as ways to generate credits include: (a) reducing loading as required through a regulatory program, (b) changing the land use by either taking agricultural use off the land or changing crops grown, and (c) implementing BMPs which are required under the BMAP. ${ }^{112}$ These requirements ensure that credits are only generated for actions that reduce nutrient loading and are not

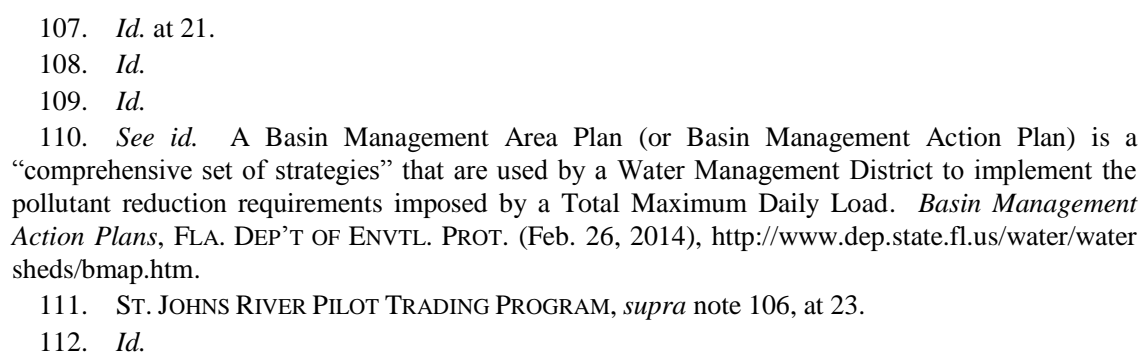
"comprehensive set of strategies" that are used by a Water Management District to implement the pollutant reduction requirements imposed by a Total Maximum Daily Load. Basin Management Action Plans, Fla. DeP'T OF Envtl. Prot. (Feb. 26, 2014), http://www.dep.state.fl.us/water/water sheds/bmap.htm.

111. St. Johns River Pilot Trading Program, supra note 106, at 23.

112. Id. 
attributable to mandated reductions or voluntary abandonment of a prior land use.

Additionally, traders may be required to use uncertainty ratios when the proposed trade involves the generation of a credit by a NPS. ${ }^{113}$ For agricultural run-off, the uncertainty ratio is $3: 1$, meaning that a potential credit-generating NPS must decrease its discharge by three pounds in order to generate a one pound credit. ${ }^{114}$ While designed to avoid "paper reductions" and promote meaningful reductions in pollutant discharge, this policy may stifle trading as it makes participation in the Trading program less economically beneficial.

The majority of trades that occurred under the pilot Trading program were transacted before the implementation of the TMDL requirements in the BMAP. ${ }^{115}$ Additionally, an overwhelming majority of the credits were generated by municipal waste-water treatment facilities (WWTF), PS polluters. ${ }^{116}$ The majority of these credit-generating WWTFs traded excess credits to Municipal Separate Storm Sewer System facilities. ${ }^{117}$ Finally, all eleven of the documented pre-TMDL trades occurred intramunicipality; for example, City of Green Cove Springs WWTFs traded 1,029.2 pounds per year to the City of Green Cove Springs (Municipal Separate Storm Sewer System) MS4 facility. ${ }^{118}$

Only three trades were generated after the initial allocation of credits. ${ }^{119}$ All three of the post-BMAP trades were similar to the preBMAP trades. ${ }^{120}$ The DEP attributes the lack of trades to uncertainty surrounding the EPA's numeric nutrient criteria. ${ }^{121}$ The main concern expressed by the DEP is whether the EPA's numeric nutrient criteria will be based on "loads" or "concentrations."122 If the criteria allow for specific quantities of loading, by individual polluters, then the Trading program is more likely to succeed. ${ }^{123}$ Allowing specific load quantities

\footnotetext{
113. Id. at 12 .

114. Id.

115. Id. at 8 ("[E]ntities were given the option of trading allocations before the BMAP was adopted.").

116. See id. at 10-11 (listing trading program statistics).

117. Id.

118. Id. at 10.

119. Id. at 11.

120. See id. (discussing the requirement that entities submit an affidavit to verify compliance with the original BMAP purpose).

121. See id. at 15-16 (listing four ways nutrient criteria create confusion over limits).

122. Id. at 15.

123. Id. at 16.
} 
would permit polluters to target their discharges with a variety of specific quantifiable reductions, whereas a standard based on concentration levels would be more difficult to reliably predict and implement. The lack of trades generated after the initial allocation gives pause to whether the Trading program can be effective throughout the entire state of Florida.

In 2013, the Florida Legislature enacted a bill that expands the pilot Trading program. The legislature granted the DEP the discretion to authorize a Trading program in an area where there is a BMAP established. ${ }^{124}$ Participation in a Trading program is voluntary and the DEP is not allowed to participate in the establishment of credit prices. ${ }^{125}$ As the statutory requirements that guided the DEP's Trading rules remain the same, it is likely that the rules promulgated to implement the expanded Trading program will be similar in scope.

Positive and negative implications can be drawn from the pilot Trading program on the lower St. Johns River Basin. There was some initial trading between WWTF and MS4 facilities, which shows that a trading system can work to allocate pollution reduction to sources where it is most economically feasible. However, the relative lack of trading post-TMDL enactment may show that both PS and NPS polluters found the Trading program economically unattractive. Since zero credits were generated by agricultural NPS polluters, it is difficult to draw a conclusion about the prospects of the program going forward. If the rules promulgated by the DEP are similar to the ones that regulated the pilot Trading program, then perhaps familiarity with the rules will foster increased interest in the program. It is likely that the only real way to increase the participation of NPS polluters in the Trading program is to prove to NPS polluters that it is in their financial interest to participate. Community outreach programs would likely be a good place to start.

\section{Great Miami Water Quality Trading Program}

The Great Miami Trading Program is one of the largest Trading programs in the U.S. ${ }^{126}$ The Great Miami River Watershed (Watershed) is located in southwestern Ohio and covers a land area of approximately 4,000 square miles. ${ }^{127}$ As of 2003, there were approximately 1,000

\footnotetext{
124. 2013 Fla. Sess. Law Serv. Ch. 2013-146 (C.S.C.S.H.B. 713) (West).

125. Id.

126. David A. Newburn \& Richard T. Woodward, An Ex Post Evaluation of Ohio's Great Miami Water Quality Trading Program, 48 J. AM. WATER ResourCes Ass'N 156, 156 (2012).

127. Id. at 158 .
} 
farmers in the Watershed. ${ }^{128}$ Approximately $70 \%$ of the land use in the Watershed is dedicated to agricultural uses, predominantly row-crop production of corn, soybeans, and wheat. ${ }^{129}$ Additionally, livestock operations - consisting of beef cattle and dairy-exist in the Watershed. ${ }^{130}$ In 2003, of the approximately 1,000 stream miles included within the Watershed, over $40 \%$ did not meet applicable standards. ${ }^{131}$ The Watershed's water resources are monitored and managed by the Miami Conservancy District (MCD). ${ }^{132}$

In anticipation of potential TMDL levels being set for waters within the Watershed, the MCD began looking for ways to achieve costeffective pollution reduction strategies. ${ }^{133}$ A report prepared for the MCD suggested that pollution reductions achieved from the implementation of agricultural BMPs may be as much as thirty times cheaper than similar pollution reductions achieved from regulated PS polluters (predominantly WWTFs). ${ }^{134}$

A Trading program established in the Watershed became operational in 2006. ${ }^{135}$ A $\$ 1$ million grant from the U.S. Department of Agriculture Natural Resource Conservation Service provided a financial boost to get the Trading program operational. ${ }^{136}$ By 2010, WWTFs contributed more than $\$ 1.2$ million to the Trading program. ${ }^{137}$

The heart of the Trading program is that farmers (NPS polluters) voluntarily reduce levels of pollution through the implementation of BMPs. ${ }^{138}$ The farmers, with the help of their local soil and water conservation district, submit projects to the MCD, which are reviewed and either accepted or denied. ${ }^{139}$ Credits are calculated based on the projected annual sum of nitrogen and phosphorous reductions multiplied by the number of years for which the contract is to run. ${ }^{140}$ Proposed

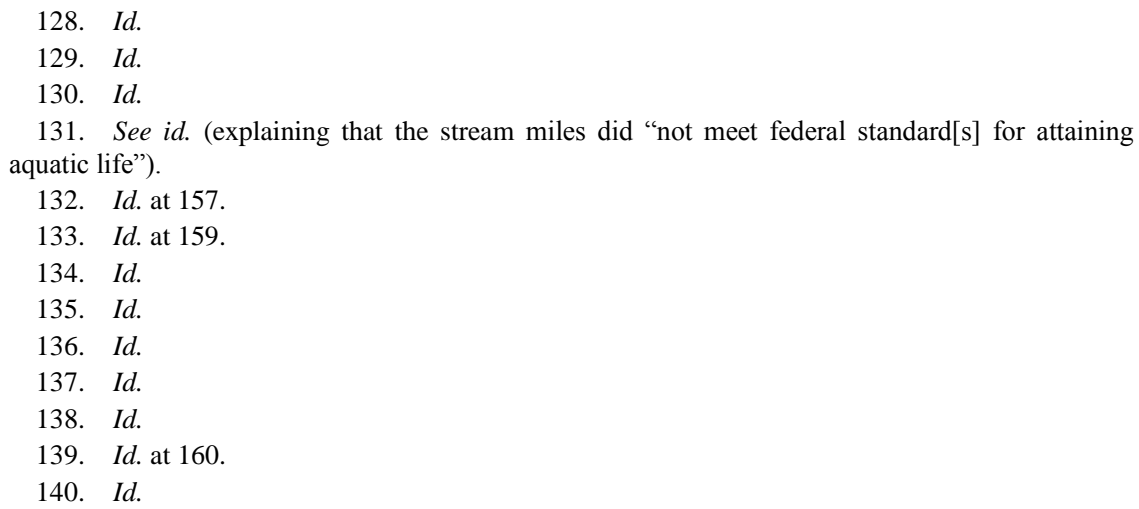


projects for credit generation are accompanied by requested prices, set by the farmers. ${ }^{141}$ This is a type of reverse auction in which the MCD accepts all bids during a given period of time (Round) that are below a maximum acceptable price. ${ }^{142}$

As the Trading program has unfolded, data suggests that farmers have discovered a dollar point at which projects will be accepted, allowing them to maximize profit while ensuring approval from the MCD. ${ }^{143}$ In the final documented Round of bids, fifty projects were proposed and $100 \%$ were accepted, a significant increase over the program's $45 \%$ history of successful bids. ${ }^{144}$ While this may show an increase in efficiency of bidding, it might also indicate a system in which the participants have discovered a fixed price at which they can be assured of receiving a maximum bid. This outcome might not be per se negative; however, it runs counter to the proposed benefit of a Trading program, which is to achieve an economically efficient result.

A second major concern with the Trading program is that a significant amount of the money that was used to fund the program came from a federal grant. It is questionable as to whether the program could have gotten off the ground or continued without the initial \$1 million grant from the federal government. However, it is promising that since the inception of the Trading program, WWTFs have contributed over $\$ 1.2$ million.

A third concern with the Trading program (and Trading programs in general) is that it might result in no net improvement to WQS. If the goal is to improve the water quality within the Watershed, it might make more sense to use the grant from the federal government to directly fund the implementation of BMPs by agricultural producers. This would likely reduce pollutant discharge from non-regulated NPS polluters while still forcing regulated PS polluters to find ways to reduce their discharges to meet NPDES requirements.

\section{Major Shortcomings of Water Quality Trading Programs}

Optimism concerning the potential for Trading programs to meaningfully improve the condition of impacted waterbodies should be tempered for a number of reasons. As compared to the relatively

\footnotetext{
141. Id.

142. Id.

143. Id. at 163 .

144. Id.
} 
successful Acid Rain Program (ARP), water quality Trading programs must contend with significantly different environmental, geographic, and economic factors. ${ }^{145}$

In 1990 Congress amended the Clean Air Act (CAA) to implement a market-based trading program with the goal of reducing sulfur dioxide $\left(\mathrm{SO}_{2}\right)$ emissions to 10 million tons below 1980 levels. ${ }^{146}$ Through the ARP, a final cap of 8.95 million tons of $\mathrm{SO}_{2}$ emissions is set from the year 2010 and prospectively. ${ }^{147}$ The cap is imposed on Electric Generating Units (EGUs), which are mainly power plants burning coal, oil, and gas to produce electricity. ${ }^{148}$ The limit of 8.95 million tons represents a nearly $50 \%$ reduction from $\mathrm{SO}_{2}$ output in the $1980 \mathrm{~s} .{ }^{149}$ While a $50 \%$ reduction in $\mathrm{SO}_{2}$ output might seem like a daunting goal, the most recent data indicates that EGUs as a whole are in compliance with the national limits. ${ }^{150}$ In 2009 EGUs emitted approximately 5.7 million tons of $\mathrm{SO}_{2}$, a full 3.8 million tons below the existing cap of 9.5 million tons. ${ }^{151}$ The 2009 emissions levels represented a $67 \%$ reduction from the emission of 17.3 million tons in $1980 .{ }^{152}$

Substantial differences exist between the ARP and current models of water quality Trading programs. First, the ARP had a broad geographic scope, whereas most Trading programs are limited to specific watersheds. The ARP was a regional program, covering pollution generating plants in over twenty states. ${ }^{153}$ Trading programs are implemented by individual states and generally encompass a smaller scope, such as a specific watershed or segment of a waterbody. Trading programs encompass smaller geographic zones, which reduces the potential impact of any single water quality Trading program.

Second, the underlying regulatory coverage of the CAA is substantially more comprehensive than the coverage of the CWA. The ARP regulates "[a]ll units over 25 megawatts and new units under 25 megawatts that use fuel with a sulfur content greater than .05 percent by

\footnotetext{
145. Longhurst, supra note 36, at 190-193.

146. Acid Rain Program, U.S. EnviRonmental Protection Agency (July 25, 2012), http://www.epa.gov/airmarket/progsregs/arp/basic.html.

147. Emission and Compliance Data, U.S. Environmental Protection Agency (Dec. 20, 2012), http://www.epa.gov/airmarkets/progress/ARP09_1.html.

148. Id.

149. Id.

150. Id.

151. Id.

152. Id.

153. Acid Rain Program, supra note 146.
} 
weight...."154 Conversely, the CWA regulates PS through the implementation of the NPDES program. ${ }^{155}$ NPS are for the most part unregulated by the CWA, which leaves potential regulation up to the individual states. The lack of a comprehensive regulatory program discourages the application of a Trading program in the context of water pollution. NPS polluters, most significantly agriculture, can decide whether to opt-in to the Trading program. While the promise of economic benefit may be enough to induce some participation, the lack of any underlying requirement to engage in pollution reduction practices leaves this decision entirely up to individual polluters.

Third, the monitoring of pollution-generating entities under the ARP is substantially more cost-effective and prevalent than monitoring of pollution generating entities under water quality Trading programs. The ARP provides for specific monitoring requirements, which are to be tracked for all participating entities. ${ }^{156}$ Generally, Trading programs rely on less comprehensive monitoring requirements. ${ }^{157}$ For regulated PS polluters, data can reasonably be gathered from effluent monitoring, which is likely already required to satisfy the NPDES permit. ${ }^{158}$ However, if NPS agriculture producers participate in the Trading program, their pollution reductions are calculated using less exact measures. For example, the Trading program in the Great Miami River Watershed allocates load reduction based on BMPs, not effluent monitoring. ${ }^{159}$ The lack of certainty surrounding monitoring pollution abatement can be addressed by the implementation of uncertainty ratios. ${ }^{160}$ Uncertainty ratios increase the cost of participating in a Trading program, however, they are implemented in order to ensure the credits generated are tied to actual reductions and not paper reductions. There is substantially more uncertainty for trading under a water quality program as compared to the more stable ARP. This uncertainty reduces the attractiveness of water quality Trading programs as a policy choice

154. Continuous Emissions Monitoring Fact Sheet, U.S. ENVIRONMENTAL Protection AGENCY (Apr. 14, 2009), http://www.epa.gov/airmarket/emissions/continuous-factsheet.html.

155. National Pollutant Discharge Elimination System (NPDES), U.S. ENVIRONMENTAL PROTECTION AGENCY (Mar. 12, 2009), http://cfpub.epa.gov/npdes/.

156. Acid Rain Program, supra note 146.

157. See St. Johns River Pilot Trading Program, supra note 106, at 12-13 (2010) (outlining conditions that would apply to trades under a pilot water quality credit Trading program in Florida).

158. Id.

159. Newburn \& Woodward, supra note 126, at 157.

160. Id. at 166 . 
and for potential participants.

Another major concern regards striking the right balance in order to properly incentivize trading between NPS polluters and PS polluters. This concern is highly dependent upon the load allocations under TMDL regulations. If the PS only need to offset a minimal amount of pollution then they will be less likely to participate in the Trading program. If the required reductions are significant and agricultural producers can offset the pollution at a significantly cheaper cost then trades may be generated.

One important factor in the success of a Trading program is that TMDL levels be set. The TMDL acts as the "cap," which is necessary for a Trading program to function as a typical cap and trade program. If no cap exists then there is no incentive for any of the participants in the system to participate in a pollution trading scheme. One interesting approach, taken by the MCD in the Great Miami Water Quality Trading Program was to differentiate polluters based on when they entered the trading system. ${ }^{161}$ WWTFs that participated in the Trading program before TMDL requirements are finalized are termed "Investors" whereas WWTFs participating after the TMDL implementation are titled "Contributors." 162 The MCD rewards Investors (or punishes Contributors) by permitting Investors to trade credits for pollution at a more favorable rate. ${ }^{163}$ Investors may trade one pound for one credit when discharging into "attained" waters and one pound for two credits when discharging into "impaired" waters. ${ }^{164}$ Contributors trade at a less favorable rate of one pound for two credits when discharging into attained waters and one pound for three credits when discharging into impaired waters. ${ }^{165}$ This approach might encourage WWTFs to invest in the Trading program, especially when TMDLs are foreseeable in the near future.

It is also important to note that a Trading program does not inherently lead to meaningful reductions in water pollution. If Company A pays farmer B $\$ 10$ in exchange for a one pound credit generated from the implementation of a BMP, Company A retains the right to use that credit by polluting one pound more pollutant than they are allotted under TMDLs. The main goal of the Trading program is to allocate the costs in a more efficient manner, easing the burden on the regulated parties.

\footnotetext{
161. Id. at 159 .

162. Id.

163. Id.

164. Id

165. Id.
} 


\section{Direct Regulation}

Many states have programs that promote or incentivize the use of agricultural BMPs. However, to date, very few programs have been adopted that require the use of BMPs or any other specific agricultural NPS pollution reduction measures. Some states, however, have in essence indirectly required the use of BMPs by creating "safe harbors," wherein the use of prescribed BMPs creates a presumption of compliance with TMDLs and WQS. An example of this type of safe harbor can be found in the Florida Watershed Restoration Act. ${ }^{166}$ This sets up a process in which the Florida Department of Agricultural and Consumer Services (FDACS) identifies and adopts BMPs for agricultural NPS. ${ }^{167}$ The Florida Department of Environmental Protection (DEP) must verify that BMPs are effective at reducing pollutant loading. Once the BMPs are verified and adopted by rule, agricultural producers who voluntarily implement the BMPs receive a "presumption of compliance" with WQS. ${ }^{168}$ Specifically, the statute requires that the rules include provisions for a Notice of Intent (NOI) to implement the BMPs and some mechanism to ensure implementation. The statute grants a presumption of compliance with state WQS to people who sign a NOI. ${ }^{169}$ For agricultural producers who choose not to sign a NOI, the statute requires they monitor water quality on their own as prescribed by the department or a water management district. ${ }^{170}$ The law also allows a NPS discharger to participate in water quality credit trading in order to "demonstrate compliance" with required pollution reductions. ${ }^{171}$

Once an agricultural producer signs a NOI, regulations contain general provisions requiring the BMPs to be properly implemented. For example, the rule adopted requiring a NOI from people who fall within the purview of the Vegetable and Agronomic Crops BMP manual provides that the "identified practices shall include the nutrient management practices listed in the manual that are applicable to the operation covered by the Notice of Intent. These nutrient management practices shall be initiated as soon as practicable after submittal of the

\footnotetext{
166. See generally Fla. StAT. AnN. § 403.067 (West 2013).

167. Id. $\$ 403.067(7)(\mathrm{c})(2)$.

168. Id. $\S 403.067(7)(\mathrm{c})(3)$.

169. Id. $\S 403.067(7)(\mathrm{c})(2)$.

170. Id. $\S 403.067(7)(\mathrm{b})(2)(\mathrm{g})$.

171. Id.
} 
Notice of Intent." 172

The Florida safe harbor approach to BMPs, on its face, appears to strike a reasonable balance between achieving nutrient pollution reduction and not imposing too onerous a burden on farmers. Nevertheless, there are a number of significant shortcomings to this approach and to solely relying on BMPs to address agricultural water pollution reduction. One shortcoming arises from the specific regulatory structure created pursuant to the Florida Watershed Restoration Act and its anemic command that farmers whose practices fall within the BMP manual's scope "shall reasonably attempt to implement the following BMPs ...."173 The manual backs away from a strong implementation requirement even further when it states "[d]epending upon the farm's site specific conditions, all of these baseline BMPs need not be implemented. Only implement those BMPs applicable for your location and production system." 174 At a certain level, the limitation on the need for farmers to implement every one of these BMPs makes sense. If, for instance, a particular farming operation has no natural bodies of water or other environmentally sensitive areas adjacent to their land, then commanding them to implement filter strips and riparian buffers makes no sense. On another level, however, those clauses could provide gaping loopholes for farmers who simply do not want to be burdened by the implementation of BMPs.

For example, a vegetable farmer may prefer broadcast fertilizer application (spreading fertilizer at a relatively even rate across an entire field) to banding (placing fertilizer in bands right in the root-zone of the plants). Theoretically, he could argue that he is not required to band his fertilizer because banding does not conform to his production system and the language of the BMP manual appears to support this argument. There does not seem to be any effective mechanism within the NOI to actually require implementation of any additional BMPs that a farmer is not already utilizing in their management practices at the time the NOI is signed. While each state approach described above has some merit, to date none has resulted in significant improvements in water quality on a large scale. Thus, additional approaches should be considered.

172. Fla. AdMIN. CODE ANN. r. 5M-8.004 (2006).

173. Florida Department of Agriculture and Consumer Services, Vegetable and AGRONOMIC CROPS BMP MANUAL (2005) (emphasis added), available at http://www.freshfromflorida.com/content/ download/32110/789059/Bmp_VeggieAgroCrops2005.pdf.

174. Id. 


\section{PROPOSED SOLUTIONS}

Nutrient run-off from agricultural operations is one of the most challenging sources of water quality degradation to address. A healthy and robust agricultural system is critical to the U.S. economy, to food security, and to farmers who typically operate on small profit margins. Thus, there are important policy reasons for not imposing too heavy an economic burden on agriculture to address water quality concerns. On the other side of the coin, however, is the important public policy goal of having water clean enough to protect human health and the natural environment, including economic resources such as fisheries and recreational values. Although reducing nutrient run-off from agriculture will be a challenging and likely costly endeavor, it will be less costly to treat the cause of the problem than eutrophication itself. ${ }^{175}$

As described above, the federal CWA does not provide for direct federal regulation of most agricultural NPS water pollution. Thus, the individual states are left with the responsibility of addressing these concerns. To date, most states have only made modest forays into regulatory and incentive-based programs for agricultural water pollution. A number of challenges have presented barriers to more serious efforts. Barriers include: (1) the lack of existing numerical nutrient criteria; (2) the technical difficulty and resources needed to determine how much of a particular pollutant, such as nitrogen or phosphorus, that a particular waterbody can assimilate without resulting in a violation of water quality standards; (3) the lack of farm run-off monitoring, ${ }^{176}$ (4) the limitations of BMPs; (5) inadequate incentives for farmers to reduce and mange nutrients; and (6) insufficient funding for research and implementation of BMPs and other nutrient management mechanisms. Each of these challenges must be addressed to achieve the substantial nutrient pollution reduction that will be needed to clean up the nation's waterways. To do this, a multifaceted approach that includes monitoring of run-off, numeric performance standards, regional treatment systems, and sources of funding for incentives and construction of regional systems is warranted.

175. SHARPLEY ET AL., supra note 10, at 3.

176. Id. at 1 . 


\section{A. Run-Off Monitoring}

One of the most important aspects of any program geared toward reducing nutrient pollution from agricultural NPS is the implementation of monitoring programs. Without monitoring data it is impossible to know how much of any particular pollutant is coming off of any particular farm. Monitoring data could help to identify which farms are the most significant contributors of nutrient run-off and thus the most in need of the imposition of BMPs or other measures to reduce run-off. Moreover, monitoring data could help to quantify the efficacy of various BMPs and to determine conditions under which the use of particular BMPs is most effective. Finally, if states begin to impose numeric performance standards or to allocate specific portions of TMDLs to specific agricultural operations, it will be necessary to have monitoring data. Without knowing the amount of pollution being contributed by a particular farm, it is difficult to determine how much of a TMDL to allocate to that farm.

NPS pollution is inherently more difficult to monitor than PS pollution. ${ }^{177}$ Numerous geographic, topographic, and climate-related variables impact the run-off and the ability to effectively monitor the effluent. ${ }^{178}$ Additionally, costs for monitoring systems of NPS may be greater because the area to be measured is generally larger in size than those required for a discrete PS polluter. ${ }^{179}$ One potential improvement to assist in monitoring NPS pollution is to turn what is diffuse into discrete, by containing run-off within conveyance systems. If agricultural NPS polluters can implement drainage systems that collect run-off, instead of allowing it to run off in a diffuse manner, then it is likely that the costs of monitoring nutrient run-off will decrease.

Monitoring is important for water quality Trading programs. Multiple Trading programs require the application of an uncertainty ratio when trades are generated from NPS to PS polluters. These ratios generally range anywhere from $1: 1$ up to $3: 1$. Uncertainty ratios require additional pollution abatement from a credit generating NPS, in order to make up for the fact that there is inherent uncertainty when monitoring NPS pollution. ${ }^{180}$ The result of uncertainty ratios is to make Trading

\footnotetext{
177. Agricultural NONPOINT SOURCe POllution: Watershed MANAGEMENT AND HyDROLOGY 305-306 (William F. Ritter \& Adel Shirmohammadi eds., 2001).

178. Id.

179. Id

180. Harry X. Zhang \& Shaw L. Yu, Linking UnCertainty Analysis with Trading
} 
programs less economically beneficial for NPS credit generators, diminishing the potential positive impacts of the Trading program. The ability to adequately monitor run-off would eliminate the need for relying on imprecise uncertainty ratios, resulting in a better economic outcome for NPS credit traders.

\section{B. Numeric Performance Standards}

There are two primary approaches to standard-setting for pollution reduction. The first approach is to establish performance standards, typically expressed in numeric form. To be in compliance with a performance standard, the polluter must demonstrate that the pollution discharge meets a specified level of "performance," regardless of how it is accomplished. Numeric performance-based standards for categories of industry are included in NPDES permits issued for PS discharges under the CWA. For example, the EPA has established by rule effluent limitation guidelines for the textile mills point source category, wool scouring subcategory. For existing sources in this industrial category that have PS discharges, the EPA has set numeric performance-based standards based on the pollutant discharge reduction attainable with the use of the "best practicable control technology currently available," also known as "Best Available Technology (BAT)." "181 For instance, if a PS within this category discharges total suspended solids (TSS), the standard is a maximum of 32.2 pounds of TSS per 1000 pounds of wool per day. ${ }^{182}$ This numeric standard is included in NPDES permits issued for these discharges. Dischargers are then free to choose which technology or other pollution reduction measures they desire, provided that such measures result in discharges not exceeding the specified daily limit. This approach has proven extremely effective for PS discharges under the NPDES program. ${ }^{183}$

The second type of standard is the design standard. Design standards

\footnotetext{
RATION DETERMinATION FROM TMDL ALlOcATION PROCESS 1 (2006), available at http://www. environmental-expert.com/Files/5306/articles/11867/309.pdf.

181. 40 C.F.R. $\S 410.12$ (a) \& (b) (2012).

182. Id.

183. Anne G. Short \& Timothy P. Duane, Regulatory Spillover: How Regulatory Programs Influence Voluntary Efforts to Adopt Best Management Practices to Manage Non-Point Source Pollution, 35 EnVIRONS: EnVTL. L. \& POL'y J. 37, 55-56 (2011). See also Houck, supra note 63, at 193 (explaining that, "[w]ithin the first years of application of BAT to industrial and municipal sources pollution loadings dropped precipitously," and "[r]eceiving water quality improved by $29 \% ”)$.
} 
prescribe the use of particular pollution control technology or management. Under this approach, a discharger meets the standard provided if it uses the specified technology, regardless of the actual performance or amount of pollution being discharged. BMPs-whether voluntary, incentivized, or mandated - are examples of design standards. As described in detail in this article, to date, BMPs adopted by NPS dischargers have not achieved significant widespread pollution reduction and vary greatly in their efficacy depending on a variety of factors such as soils, geology, location, and climatic conditions. Given the success of performance standards and relative lack of success for design standards for water pollution reduction, it is worth considering whether, at least in certain circumstances, performance standards would be more effective in the NPS arena.

Performance standards offer many benefits. Performance standards ensure greater certainty that, if met, they will actually accomplish the desired water quality improvements. In comparison, because design standards contain so many factors that can influence efficacy, they may or may not accomplish the desired pollution reduction. In addition, performance standards establish a bright line that makes it easy for both dischargers and regulatory agencies to determine whether the discharger is in compliance, and this simplifies the compliance enforcement process. Performance standards have the added benefit of encouraging innovation - the use of newer technology with improved efficiency and effectiveness. It is in the interest of dischargers who must meet performance standards to develop cheaper and better technology and other pollution reduction measures. Once dischargers develop better technologies, others could adopt these innovations, and this could result in widespread success. Finally, a major benefit of the numeric performance standard is that it facilitates trading programs. Dischargers who perform better than the specified performance standards will have easily measured pollutant reductions that can be used to determine the number of credits available for trading. The use of numerical performance standards rather than design standards will make it easier to determine the number of credits without the need for estimates and the application of uncertainty factors. Thus, dischargers will have more certainty in determining whether pollution reduction measures will be cost effective in the trading market and regulatory agencies will have more certainty in tracking credit trading. 


\section{Regional Treatment Systems}

Due to the variability of BMP efficacy and the costs of farm-by-farm regulation and run-off treatment, regional nutrient management and runoff treatment may be more efficient and effective in many situations. Although certain agricultural operations - such as grain farms - are often very large, some farms - including many vegetable farms, family farms and organic farms - are of a much smaller scale. For regions that have multiple small farms, the imposition of numeric performance standards on each farm may be overly burdensome. An alternative approach could be "regional treatment systems" in which run-off from multiple farms is collected and treated. Compliance with numeric performance standards would be measured at the point of discharge from the regional treatment system. By collecting discharge from multiple farms in a particular watershed into one regional treatment system, farmers can share costs and take advantage of economies of scale. Currently, efforts are underway in Florida to collect run-off from a number of farms in one region and treat the water collectively. The farms there are already implementing BMPs and thus reducing nutrient run-off to some extent before the water enters the regional treatment system. However, BMPs are not sufficient to achieve desired reductions. Thus, the collected runoff flows through a regional treatment system that can significantly reduce nutrient levels beyond what was accomplished with BMPs.

The most successful, albeit extremely costly, example of a regional treatment system is in the Everglades Agricultural Area (EAA), located south of Lake Okeechobee in south Florida. The EAA sits between Lake Okeechobee and the state and federal lands that comprise the core of the Florida Everglades. The EAA consists of approximately 640,000 acres of agricultural land. Pursuant to statute, the farms in the EAA are required to implement BMPs. ${ }^{184}$ BMPs have reduced phosphorous loadings by approximately 55\%. ${ }^{185}$ However, this reduction was insufficient to reduce phosphorous levels to the $10 \mathrm{ppb}$ water quality criteria that applies in the Everglades. Thus, Florida has constructed Stormwater Treatment Areas (STAs) on approximately 63,000 acres south of the EAA farms. NPDES permits containing numeric performance standards are required for the PS discharges from the STAs.

184. Fla. Stat. ANN. § 373.4592(4)(f) (West 2013).

185. JenNifer LeEds, South Florida Water Management District, Stormwater TREATMENT AREAS \& EVERGLADES RESTORATION (2012), available at http://waterinstitute.ufl.edu/ symposium2012/downloads/presentations/LeedsJ_BallroomF_WI_SYMP_2012.pdf. 
The STAs have reduced phosphorus loadings by an additional $79 \% .{ }^{186}$ While neither BMPs nor STAs alone would be sufficient to reduce loadings to the point necessary to comply with WQS, the combination of on-farm BMPs and the collection of farm run-off into STAs has resulted in water entering the Everglades being approximately fourteen times cleaner than water leaving Lake Okeechobee. ${ }^{187}$ After treatment in the regional STAs, some water is close to meeting the very stringent $10 \mathrm{ppb}$ numeric nutrient criteria for phosphorus in the Everglades. ${ }^{188}$

\section{Sources of Funding}

Any of the methods proposed in this article for reducing the contribution of agriculture to water quality will require funding. Setting numeric nutrient criteria and establishing and allocating TMDLs can be very costly for state governments. Implementing BMPs, whether done on a voluntary basis or required by regulation, can impose substantial financial burdens on farmers, many of whom operate on small profit margins. Moreover, the construction of regional treatment systems such as the ones in the Everglades Agricultural Area is extremely expensive. Accordingly, actors should consider a variety of creative finance mechanisms. State and federal governments could provide additional financial incentives to farmers who implement BMPs or utilize other technologies or practices to reduce run-off. This could be accomplished through direct financial support-which is already being done in a limited fashion by the EQIP program-or through Payment for Ecosystem Services.

\section{Fertilizer Tax}

Section 576.045 of the Florida Statutes imposes various fees on the use and distribution of fertilizers in the state of Florida. Among other inspection and licensing fees, the state collects a $\$ 0.50$ fee on the sale of every ton of fertilizer that contains nitrogen or phosphorus within the state. ${ }^{189}$ FDACS uses the proceeds for activities that promote implementing BMPs and achieving state WQS. ${ }^{190}$ Specifically, the funds

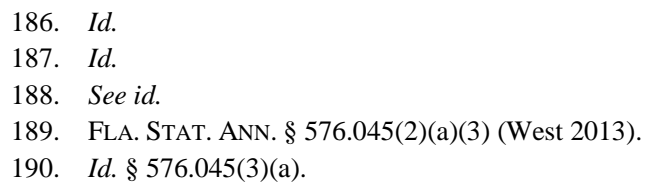


are to be used for "[r]esearch, development, demonstration, and implementation of suitable interim measures, best management practices, or other measures used to achieve state water quality standards for nitrogen and phosphorus criteria." 191 The FDACS may attempt to reach these goals by using the funds for "cost-sharing grants, technical assistance, implementation tracking, and conservation leases or other agreements for water quality improvement." ${ }^{, 192}$ Essentially, the funds collected from the fertilizer fee are to be used to implement BMPs or other technical programs, which will help reduce the harmful impacts of nutrient run-off. This type of tax could be expanded to generate funds needed to provide financial incentives to farmers to reduce pollution. An added benefit of this type of tax is that it increases the cost of fertilizers, which may in turn provide a financial disincentive for farmers to use large amounts of fertilizer. This may ultimately result in a reduction of nutrient pollution due to fertilizer use. Of course, the tax would need to be significantly higher than Florida's $\$ 0.50$ per ton tax to provide a significant disincentive.

\section{Tax to Finance Regional Treatment Systems}

A model for a targeted tax to provide funding to construct regional treatment systems is the Everglades Agricultural Area Privilege Tax. Section 373.4592(6) of the Florida Statutes sets forth a taxing program that imposes an "agricultural privilege tax" within the EAA. The tax is an annual assessment "for the privilege of conducting an agricultural trade or business on" each acre of real property within the EAA. ${ }^{193}$ Initially imposed in 1994, the tax steadily increased from $\$ 24.89$ /acre to \$35/acre in 2013. ${ }^{194}$ The Florida Legislature included a possibility for relief from the tax if the agricultural landowners implemented BMPs that reduced phosphorus loading by a specified amount. ${ }^{195}$ Landowners are encouraged to implement BMPs in order to generate "incentive credits," which may be used to reduce the imposed privilege tax to a statutorily mandated minimum tax (\$24.89/acre). ${ }^{196}$

Revenue generated from the privilege tax is to be used by the South

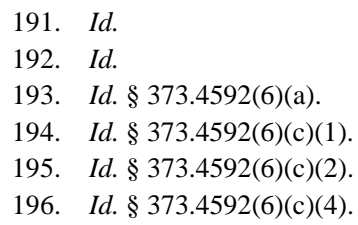


Florida Water Management District to implement the "Long-Term Plan." 197 The Long-Term Plan is the district's proposal to meet WQS in the Everglades region. ${ }^{198}$ The district's Long-Term Plan is implemented using regional Stormwater Treatment Areas and Flow Equalization Basins. ${ }^{199}$ The tax is used to fund projects that mitigate the increased nutrient loading that results from agricultural operations. Through this method, the water management district directly imposes a financial responsibility upon the polluter, as opposed to relying on voluntary or incentive-based programs.

The imposition of these types of taxes could provide much-needed funding to develop and implement pollution reduction technologies, including regional treatment systems. By sharing the burden among all fertilizer users based on the amount of fertilizer used, the burden on individual farmers would not be onerous. Furthermore, funds can be directed to farmers in particular need of financial assistance or to locations where there is a particular need to reduce pollutant run-off.

\section{CONCLUSION}

It is inarguable that agricultural production is an essential component for the continued way of life in the U.S. It is also inarguable that modern commercial agriculture contributes significantly to the degraded conditions in our nation's waterbodies.

Regulations designed to improve water quality have failed to adequately reduce harmful pollution from NPS. The CWA has to a large extent reined in pollution from PS, but it fails to deal with the whole problem of water pollution. The CWA leaves the regulation of NPS pollution to the states, which has led to patchwork and divergent methods. This paper has not addressed whether the states are the appropriate government units to address NPS pollution; rather, it has attempted to summarize the various approaches the states have taken.

The majority of regulations addressing NPS pollution attempt to reduce pollution through voluntary methods. Non-mandatory BMP programs and financial assistance are the two most popular voluntary approaches. Some states have experimented with market-based

\footnotetext{
197. Id. § 373.4592(6)(c)(6).

198. Id. § 373.4592(3).

199. SOUth Florida Water Management District, Restoration Strategies Regional WATER QUALITY PLAN 4 (2012), available at http://www.sfwmd.gov/portal/page/portal/xrepository/ sfwmd_repository_pdf/rs_waterquality_plan_042712_final.pdf.
} 
approaches in order to address NPS pollution. Trading programs are intended to allocate the burdens of reducing pollution among all polluters in an economically efficient manner. Trading programs set an effective cap that total pollution may not exceed. Part of the problem with trading programs in the context of water pollution is the lack of progress in setting TMDLs, which serve as the cap. Without a numerical limit, it is impossible to make economic choices about whether to trade and what the value of a credit is. Trading programs might help reduce costs for polluters once regulation of water pollution is addressed more comprehensively, but they are likely only a part of the solution.

Finally, the most reliable method for addressing NPS pollution is through direct regulation. Direct regulation, whether in the form of a tax, mandatory BMPs, or load allocation, allows for a measurable standard by which success may be easily measured. There are numerous reasons why direct regulation of NPS polluters has lagged behind voluntary and market-based approaches. However, if states that are burdened by significant agricultural NPS pollution desire a reliable option for achieving meaningful improvements in water quality, they need to seriously consider direct regulation of NPS polluters.

It is likely that there will be no meaningful changes to the CWA, which would comprehensively address NPS pollution. The current statecentric approach is here to stay, and regulators should be knowledgeable about the available options in order to make the right choices for their particular states. 